\title{
THE POTENTLAL USE OF GUINEA PIGS AND MICE AS AN ALTERNATIVE TO SHEEP AND GOATS FOR SAFETY TESTING OF PESTE DES PETITS RUMMNANTS LIVE VACCINE
}

\author{
Kamel, N. A. \\ Velcrinary Serum and Vacclne Rescarch Instllute. \\ Ablasia. Calro. Egypl.
}

\begin{abstract}
ARSTRACT
Three sterile. polent and idenlified separatc balches of the locally manufactured live pestes des petils ruminanis virus (PPRV) vaccine were subjected lo safely tesing in ro. denis (Guinea pigs and mice) as well as in small riminanls (sheep and goals). For each vaccine balch. chree suscepuble animals of each of sheep and goats. induding one pregnant animal per specles were inoculaled subculaneously. each with $1 \mathrm{ml}$ of the vaccine containing $S \log _{10} T C D_{50}$ of the reconstiluted randomly selecled. statistically representalive samples per batch Same humber \& stalus of aninals were hetd as contacl control. inoculated S/C. each with the same volume of nomal physiological saline solution as a placebo. Corresponding lests in rodents were done using 10 young and 6 pregnant Gulnea plgs as well as 10 unweaned and 6 pregnant mice for each of the three vaccine balches. Five young and 3 pregnant Guinea plgs received an invamuscular dose of $0.5 \mathrm{ml}$ of $6 \log _{10} 1 \mathrm{ClD}_{50} / \mathrm{ml}$ per head/batch. The same close was glu. en intrapertioneally per head of the rest half number of animals. Ten unweaned and 6 pregnant mice recelved an intraperiloneal dose of $0.1 \mathrm{ml}$ of $6 \log _{10} \mathrm{TCl} \mathrm{D}_{50} / \mathrm{ml}$ per head per balch $A$ similar number of control rodents were given the same dosing vol. ume of normal physiological saline solution per corresponding roules of inoculations, as a placebo.
\end{abstract}

All lesied small numinants as well as rodents remained absolutely healthy through. out a three weeks observation post inoculateions. Pregnant animals gave birh to normal healthy suckling offsprings. Non laclating rodenls. sacrificed for post-morlen examinattons, were absolutely negallue to gross pathological findings.

Results oblatned would be considered a convincing cvidence encouraging the orien. Iotion to test the locally produced PPRV vaccine safely in rodents as an allernative 10 
sheep and goals. This alternation might save a lol of expenses, time and effort spent in performing one crllerion of the qualily control integration system.

\section{INTRODUCTION}

Peste des pelits ruminants (PPR) is an acute contaglous vlral disease of small ruminanis caused by a Morbillivirus in the famlly Paramyxovirldae (Gibbs et al., 1979). PPRV virus is transmilted by aerosols between animals living in close contact (Lefevre and Diallo, 1990). Infccted animals show clinical signs of fever. oculonasal discharges, stomatils. dlanhoca and pneu. monia (Taylor et al., 1990). The disease occurs in most African countries south of the sahara and north of the equator (ONE. 2004), and In nearly all Middle Eastem countrles up to turkey (Furleg et al., 1987: Leferre et al., 1991; Perl et al.. 1994 and Taylor et al., 1990). PPR is also wide-spread in India and soult-west Asla (Shatla et al., 1989). The morbidity rate can be up to $100 \%$ and in severe outbreaks. with 100\% mortallty. In milder outbreaks. the mortallty rate may nol exceed 50\% (ODE, 2004).

The OIE International Commillee endorsed the use of homolugous live PPRV-vaccine (PPRV 75/1) (Diallo et al.. 1989) In countrites that have declded to follow the "OlE Palliway" for epidemiological survelllance for rnderpest in order to avoid confusion when serological surveys are. performed (OE, 2000). Safety testing of this vaccine is done in rodents (Gulnea pigs and mice) (OIE, 2004).

Nevertheless, the corresponding locally produced PPRV-vaccine is sull tested for safety in small ruminants. Hence, the object of the study presented was alming at performing an evalua. tive comparison of the safety test as carrted out in both rodents and small rumlnants for thrce separate batches of the PPRV-vaccine, locally produced for exportation purposes.

\section{MATERLAL AND METHODS}

\section{Live PPRV-vacclne batches:}

Three separate batches of this vaccine were manufactured as routlnely produced. The substrate was vero cells (Yasumura and Kawatka, 1963) and the inoculum was the vero ccllattenuated PPRV. that was derlved (rom a local isolate designated Egypt-87 (House, 1987). Vaccine batches were stored lyophllized: Into a $\left\{-20^{\circ} \mathrm{C}\right\}$ cabinel. They were subjected to identity. sterflity and potency tesLng through recoinmended evaluatlve parameters (OIE, 1996; 2000; 2002 and 2004). 


\section{Safety testing:}

\section{Io small ruminants:}

Randomly selected. three susceplible. hearis per each of the two specles, sheep and goats including a pregnant animal per spectes for each of the three vaccine batches were inoculated subcutaneously each wth $1 \mathrm{ml}$ containing $5 \log _{10} \mathrm{TClO}_{50}$ of the reconstituted randoinly selected. slatistlcally representative samples for each vacclne batch. Three heads per species status were held as contacl control inoculated S/C. each wtth a similar volume of normal physíoluglcal saline solution as a placebo.. All animals were ascertalned seronegative lo PPRV lhrough proven freedom of their sera samples collected Just prior to inoculations of PPRV-antibodles. Parameter used was the virus neutrallixation lest (VNT) (OE, 1996, 2000 and 2004). They were kept undes keen daily clinical observation throughout a three weeks post inoculations. after which time all animals were bled and thelr serum samples were subjected to VNT (Descriptive detalls are found In table 2).

in rodents: safety test was performed according to (OlE. 2004: with modifications of the number of animals):

\section{Gulnea pigs:}

Five young as welt as 3 pregnant animais for each of the three vaccine balelics wcre inoculated I/M. each with $0.5 \mathrm{ml}$ of $\left.6 \log _{10} T \mathrm{TClD}_{50} / \mathrm{m}\right)$ of the reconstituted randomly selectively. representalive saniple for each vaccine batch. A similar number and status of animals were inoculated I/P with the same vaccine dose.

\section{Mice:}

Ten unweaned as well as 6 pregnant mice for each of the three vaccine balches ivere innculat. ed I/P. each with $0.1 \mathrm{ml}$ of $6 \log _{10} T C I D_{50} / \mathrm{ml}$ of the reconstituted randomily selecled. statistically representative samples for each vaccine batch.

Corresponding number and status of both guinea pigs and mice were held as control. inoculated. per corresponding routes. each with a similar volume of normal pliyslological saline solution as a placebo (descriptive delalls are found in table 2).

All test rodents were keenly observed for 3 weeks post inoculations: afler which Imie: num lac. tating animals were sacrifleed. subjected to post-mortem examination.

The methods followed for P.M. examinations were essentlally thuse mentioned In (Thomson's Special Veterinary Pathology, 1985). 


\section{RESULTS}

\section{Sterlity and potency of three PPRV-vaccine batches:}

Table I shows an absolute negativity to microblological contaminants as tested for the three vaccine batches. It shows. also a $\mathrm{TClO}_{50}$ PPRV titres ranging between 6.0 and $6.3 \log 10$ per mi of reconstituted vacelne for the 3 batches.

\section{Safety of the three PPRV-vaccine batches:}

\section{La small ruminants:}

It was found that all animals Included in the test remained absolutely healthy through a 3 weeks observation pertod post Inoculations. Pregnant animals gave birth to nurmal healthy suckling oflsprings. Virus inoculated animals seroconverted. Conirol ones remainod seronegauve.

\section{In rodents:}

It was revealed that not a single sign of ill-healch could be detected In any animal throughout an observation period of 3 weeks post inoculatlons. Pregnant animals gave ljith to norilial healthy suckling offsprings. Gross pathological lesions were completcly alusent in sacrificed nonlactating anlmals.

Results of safety testing of the three PPRV-vaccine batches are given in table 2 .

\section{DISCUSSION}

With an expanding global population. the demand for foodsturfs in the future will become ever greater, resulting in increased pressures on the agriculture and liveslock Industries for higher levels of production. In the case of liveslock. control of the major eplzootic diseases will be a prime requirement if increased production is to come froin making use of the potential for animal husbandry in the develuping world. Veterinary vaccines are a major factor in programmics to bring the economically important diseases under conlrol.

Vaccination is a major weapon in the control of many viral diseases of humans and their domestic and pet animals (Brown, 1990). There is no doubt that vaccines have made an enunnous Impact on the heallh and consequenly the productuvity of the reciplents (Brown, 1997).

The locally produced live PPRV-vacclne. as dertved from a local isolate. designaled (Egyp(-87). 
was and stlll enjoying much interest, as mullions of doses are being exported to countries of the Arablan gulf area (VSVRI rocords. 1996-2005). At the time of its initlal production. sctentific quallity control committee endorsed the utllization of susceptible small ruminants for safety testing of PPRV-vaccine batches. Since that Ume. scveral tcns of such vacclne batches have successfully passed the quality control measures applied per batch (Records of the CLEVB, 19962005).

In vlew of the fact that each vaccine batch is subjccted to quality control crlteria testing for identity. sterlity. potency and the safety lest is done in small ruminants: it was a good iclea to think for applleation of the safety test in reconimended rodents which are guinea-pigs and inice \{OIE, 2004\}. Cognition of the factual identincation of the master as well as the working seed virus strain as a prerequisite for perfect vaccine manufacture coupled with the nature of solessess of source; encouraged the orientation to the trend of rodents as an alternation to sinall rumb. nants. Such an orlentation is not extra-ordinary in $1 / s$ kind. since it is supported by internallonal recommendations (OLE, 1996, 2000 and 2004).

In the present scudy. susceptible sheep and goats exposed to a S/C PPRV-vaccine dose as masslve as 100 times $\left(5 \log _{10} T C 1 D_{50}\right)$ the feld applied dosc $\left(3 \log _{10} T C\left(D_{50}\right)\right.$ falled to display the least sign of Bl-health, disease syndrome or side reacllons. Moreover, contact control antmals remained seronegalive, denotlng a status of non-virus shedding from invculated animals which seroconverted. These results were found with the three vaccine batches that were manufactured and tested at separale occasluns. Such a reproducibility was found pieviously with scveral tens of batches of this vaccine (CLEVB, 1996-2005).

On applying the safety of the PPRV-vaccine batches in rodents, pregnant anlmals were deliberately included in the lest for the three balches. and the total number of both Guinea plgs and mice was muluplied for more convenlence in interprelating the obtalned results. It was of interest to find out that all pregnant rodents gave birth to normal suckling olfsprings. Morenver, not a single sign of ill health. side reactions or disease syndrome could be detected in lnoculated rodenis. even though recelving doses as drastlc as $5 \log _{10} \mathrm{TClO}_{50}$ of the reconstltuted PPRVvaccine. These results as reproduced with three vacclne batches manufactured at different occasions would encourage the reliance on rodents for salety lesting of this vacclne. It is worthy to mentlon that the standard operating procedures described in FAO.Animal Production and Health paper. 118 (1994), gave a detailed description of the methods for safety testing of rinderpest vaccine in rodents (guinea-plgs and mice). These methods are exaclly the same, 10 the most Rine dctails. as those produced in Manual of Diagnostic Tests and Vaccines for Terrestrlal Nitmal, 5th edition. 2004, for safety test'ng of PPRV-vaccine in the same species of rodents. which 
were also followed through carrytng out the present wurk. It is well recognized that both rinderpest and PPR viruses are morblliviruses sharing a strong antigenic relationshlp (Gibbs et al.. 1979).

Provost et al. (1987) dernonstrated the procedures for safely testing of contaglous bovine pleuropneumonla vaccine in gulnea plgs and mice. These procedures are very approximating those mentloned above for both rinderpest and PPR vaccines.

It is worth mentloning that the safety of the locally produced PPRV-vacclne as performed in small ruminants, is amply documented (Khodeir and Mouaz, 1998; Mouaz et al., 1998: Abecr. 1997; Afof, 1998; Hanen, 1998; Hanan, 2000; Nahed et al., 2000; Samla et al., 2000; Nabed et al. 2004 and Lalla et al., 2005).

The results oblained through the present work would be considered as a convinclng evidence on the rellabllity of rodents as an alternalive to small runinants for PPRV-vaccine salety testing. 
Table 1. Sterility and potency testing results of three PPRV-vaccine batches (live)

\begin{tabular}{ccc}
\hline PPRV-vaccine batches & $\begin{array}{c}\text { Microbiological } \\
\text { sterility icsting }\end{array}$ & $* *$ Potency $(\log 10)$ \\
\hline \multicolumn{3}{c}{ Absolute negativity to: } \\
2 & bacleria, & 6.3 \\
3 & fungi and & 6.0 \\
\hline
\end{tabular}

*: as carried out according to standard operating procedures (FAO, 1994).

**: designated as geometric mean $1 \mathrm{ClD}_{50}$ vicus titre per $\mathrm{ml}$ of reconstituled randomly selected, statistically representative samples per vaccine batch (FAO, 1994). 
Table 2. Callective results of safety testing of three batches of PPRV-vaccine (live) in small ruminants as well as

\section{in rodents}

\begin{tabular}{|c|c|c|c|}
\hline \multirow[t]{4}{*}{ PPRV-vaccine (live) } & \multicolumn{3}{|c|}{ Safety testing per batch in: } \\
\hline & 6, small ruminants & \multicolumn{2}{|c|}{ 32, rodents } \\
\hline & \multirow{2}{*}{$\begin{array}{c}\text { 3. Sheep } \\
\text { including one pregnant animal/species }\end{array}$} & 16. guinea pigs & 16 , mice \\
\hline & & 10. young 6. pregnant & 10. unweaned 6.pregnant \\
\hline \multirow{3}{*}{$\begin{array}{c}\text { Three separate } \\
\text { batches }\end{array}$} & $\begin{array}{l}S \log _{10} T C I D_{30} S / C \text { dose/head. } \\
\text { 3. hesads/species status. contact control }\end{array}$ & $\begin{array}{l}5\left(5 \log _{10} \text { TCID } D_{\text {Sa }} 1 / N_{\text {: }}\right. \\
\text { dose/head. per } 5 \text {, young } \\
\text { and } 3 \text {, pregnant. Same } \\
\text { dose } 1 / \mathrm{P} \text { per head/rest } \\
\text { half. Similar No/siatus. } \\
\text { control }\end{array}$ & $\begin{array}{l}5 \log _{10} \mathrm{TCI} / \mathrm{D}_{0} \mathrm{I} / \mathrm{P} \\
\text { dose/head. Similar } \\
\text { No./status, control }\end{array}$ \\
\hline & & & \\
\hline & $\begin{array}{l}\text { 1. Alt animals remained absolutely } \\
\text { healthy throughout an observacion } \\
\text { period of } 3 \text { weeks post inoculations. } \\
\text { 2. Pregnant animals gave birth to noma! } \\
\text { healthy suckling offsprings. } \\
\text { 3. Inoculated animals seroconverted. } \\
\text { 4. Control ones remained seronegative }\end{array}$ & \multicolumn{2}{|c|}{$\begin{array}{l}\text { 1. Not a single sign of ill-heasth could be delecied in any } \\
\text { animal throughout an observation period of } ; \text { iveeks post } \\
\text { inoculations. } \\
\text { 2. Pregnant animals gave binh to normal healthy suckling } \\
\text { oftsprings. } \\
\text { 3. Post-mortem examinations revealed absolute negativity } \\
10 \text { gross pathology. }\end{array}$} \\
\hline
\end{tabular}




\section{REFERENCES}

Abeer, M. A. (1997) : Evaluation of a speciflc peste des petils ruminanls vaccine prepared from a local virus straln. M. Vet. Sct. Thesis. Fac. Vet. Med. Calro Univ.

Afar. A A. (1998) : Studies on thermostable PPR virus vaccine. Ph.D. Thesis. Fac. Vet. Med., Calro Univ.

Brown, F. (1990): The potential peptides as vaccines. Semin. Virol., 1: 67-74.

Brown, F. (1997) : Viral vaccines: In Vaccine Manual: FAO-animal production and health series No. 35 .

CLEVB (1986-2005) : Records of the Central Laboralory for Evaluation of Veterinary Blologlcs. Abbasla, Calro.

Diallo, A. Taglor, W. P.; Leferre, P. C. and Provost, A. (1989) ; Attenuation diune souche de virus de la peste des petits ruminants: candidat pour un vaccin homologue vivant. Rev. Elev. Med. Vet. Pays Trop., 42: 31 1-319.

FAO (1894) : FAO Animal Produclion and health. Paper No. 118.

Furley, C. W.; Taylor, W. P. and Obi, T. U. (1987) : An oulbreak of pestc des prlits ruminants in a zoological collectlon. Vet. Rec.. $121: 443-447$.

Glbbs, E. P. J.: Taylor, W. P.; Lamman, M. J. P. and Bryant, J. (1979) : Classification of peste des petits ruminants virus as the fourth member of the genus Morbllivirus. Intervirology. 11. 268-274.

Haraa, M. S. M. (2000) : Advanced pathological studles of pest of small ruminants and its vaccine in sheep and goats. Ph.D. Thesls. Cairo Univ.

Haman. S. A. R. (1998): Metabollc and endocrine changes assoclated with active Immunlization of goats against peste des petits ruminants virus. Ph.D. Vet. Thesls. Physlology. Cajro Univ.

House, J. A. (1987) : Characlerzation of a peste des pelits ruminants (PPR) isolated from Egypt. Memorandum for the record) Plum Island Animal Disease Centre. N.Y.. USA.

Khodelr. M. H. and Mouaz, M. A. (1998) : Preparation of a specific pesle des petits ruininants (PPR) virus vaccine. Vet. Med. J. Giza, 46 (4B): 709-717.

Lalla A Sadeek; Fatma, S. Mohamed; Hanan, S. Abdel Raouf; samia A. Ayad and Daoud, A. M. (2005) : The use of trehalose in the preparation and preservation of rinderpest and pesce des petils ruminants vaccines. 4 th Int. Scl. Conf., Mansoura. 5-6 April.

Mansoura, Vet. Med. J.

Vol. VU, No. 1. 2005 
Leferre, P. C. and Dlallo. A. (1890) : Peste des petlls ruminants. Rev. Sct. Tech. Off. Int. Eplz.. 9: $951-965$.

Leferre, P. C.; Dlallo, A.; Scheakel. F.; Hussein, S. And Stakk, G. (1991): Serological evldence of peste des petits ruminants in Jordan. Vet. Rec. 128: 110.

Mouaz, M. A; Gehan, K. Mohammed; Khatrat A. Elín; Elda I. El-Debegy and Kbodelr, M.

H. (1998) : Evaluation of Immune response in Egypllan balady sheep vaccinated with attenuated RVF and PPR vaccine. Asslut Vet. Med. J., 38 (76).

Nahed A. Kamel; Hanan, S. Abdel Raouf; Hanan M. S. El-Zawahry; Laila A. Sadeek and Fatmo 8. Mohamed (2004): The production and evaluatlon of a standard diagnostlc peste des pellts ruminants (PPR) hyperimmune serum prepared from the Egyptian antigen (Egypt-87). Egypt. J. Immunol., 11 (1): 09-14.

Nahed A. Eomel: Hussela, A. B. M.; Samla, A. A. Ayad and Mouaz, M. A. (2000) : Response of pregnant sheep and goats to a specific vaccine for peste des petits rumluants. Vel. Med. J. Gika.. 48 (4): 617-624.

OLE (1996) : OIE Manual of slandards for dlagnostic lests and vaccines: Lisl A \& B diseases of mammals. blrds and bees.

OIE (2000) : Manual of standard for dlagnostic lests and vaccines. 4th Ed. Chapter 2.1.5.. peste des peuts ruminants. Pp. $1-14$.

Ore (2002) : Peste des petits ruminants, Iist A disease (A050), World Organizalion for anImal health.

OTE (2004) : Manual of diagnostlc tests and vaccines for Ierrestrlal animals. 5th Edition.

Perl, S.; Alerander, A.; Yakobson, B.; Nyska, A.; Harmello, A; Sheikhat, N.; Shlmshony, A.; Davidsoa. N.; Abramson, M. and Rapoport. E. (1994) : Peste des pellts rumlnants (PPR) of sheep in Israel: case report. Israel J. Vet. Med., 49: 59-62.

Provost, A.; Perreau, P.; Beard, A.; Legofr, C.; Mortel, J. L. and Cottew, G.S. (1987): Contaglous bovine pleuropneumonla; a review. Rev. Scl. Tech. Ofr. Int. Eplz. 6 (3): 625-679.

Samia A. Ayad; Mouaz, M. A. Nahed, A. H. Kamel; Afaf Abdel Wahab and Daoud, A. M. (2000) : Thermostabilizing potentlal of L-glutamic acid monosodium salt and other factors Improving the quality of peste des petits ruminants virus vaccine. Egypl. J. Immunol.. 7 (2): $21-27$.

Shalla. M. S.: Purushothaman, V.; Bbsavar, D.; Venngopal, K. and Veakatesan, R. A. (1989): Peste des pells ruminants in India, Vet. Rec., 125: 602. 
Taylor, W. P.: Albusaidy. S. and Bartett, T. (1990) : The epidemiology of peste des petits ruminants in the Sultanate of Oman. Vet. Microblol., 22: 34 I -352.

Thomson (1995) : Thomson's speclal veterinary pathology. 2nd Edition.

VSVRI (1996-2005): Records of the Velernary Scrum and Vaccine Research Iristlute, Abbasia. Calro.

Yasumura, Y. and Kawatika. Y. (1963) : Studies on SV4O virus in tissue culture. Niton Rin. sho. $21: 1201 \cdot 1215$. 
Kame1. N. A.

الملخص العريى

إمكانية إســتخدام خنازبــر غينيا والفئران كبديسل للأغنــام والماعـــز

لاختبار سلامة اللقاح المى لطاعون المجترات الصغيرة الحىى

\author{
ناهــد عبداللـــــــل كامل \\ معهد بعرث الأمصال راللقاهات البيطرية - العباسية - القاهرة - مصر
}

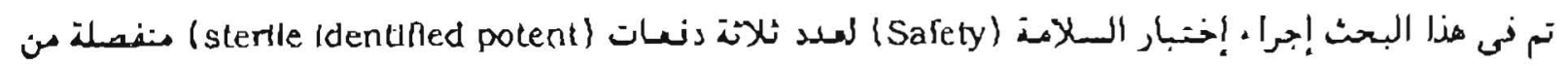

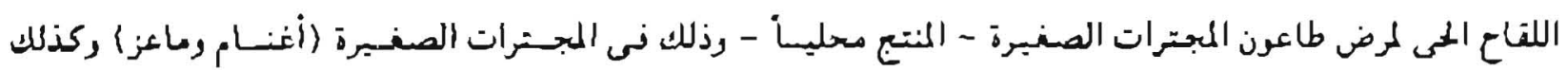

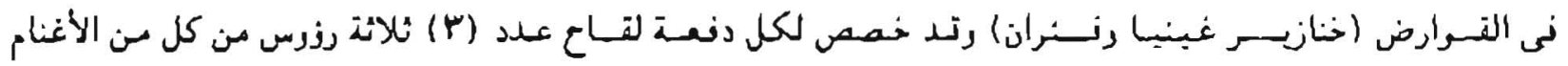

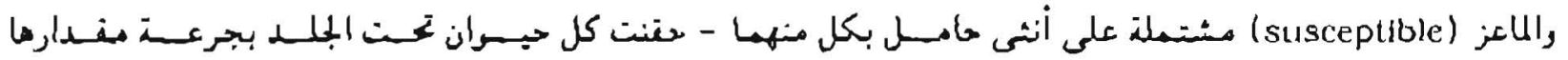
(6 log 10 'TClD 10 /ml)

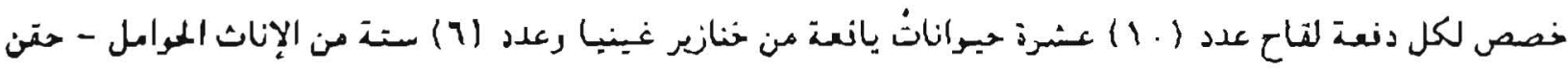

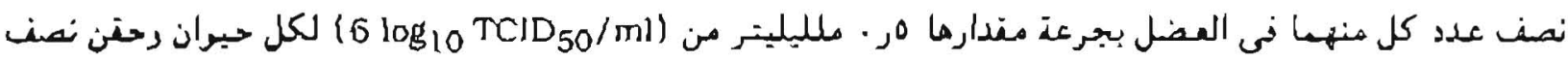

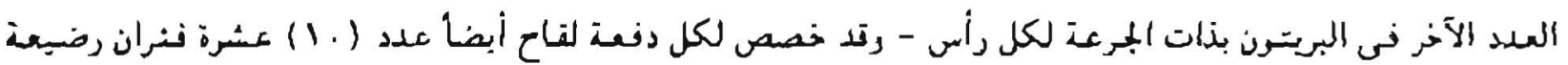

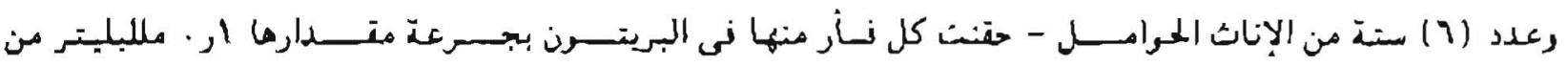

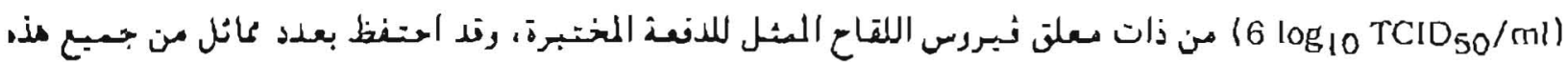

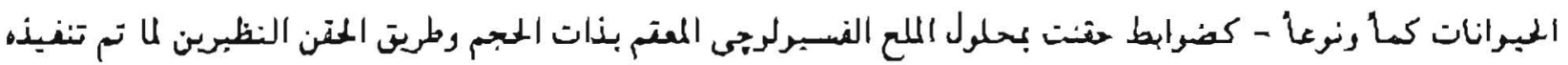

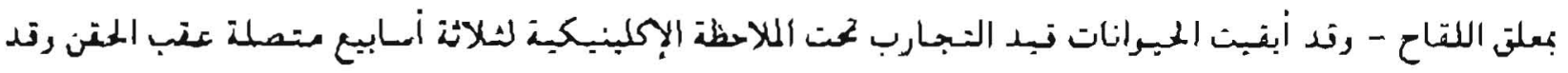

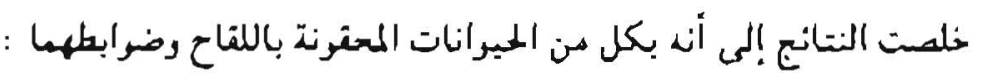

$$
\text { أرلا : لم المبترات الصغيرة : }
$$

ا- بقيت جسيعهنا بهالة صحية جيدة ولم يستدل على حدرث أية أعراض مرضية أو آثار جانببة أر ظراهر غهر

$$
\text { طبيمية. }
$$

Y- أنتجت حواملها مواليد طبيعية ربحالة صسية جيدة وتتارلن غذاثها من أئدا ، الأمهات بصورة طبيعبة. 
r- بثيت الضرابط Seronegatlve يبنما حدث تحول نى المبيوانات المحقرنة بنبروس اللناح ( $\left(P L^{\prime} R V\right.$ ncutralizing antibody seroconversion)

$$
\text { ثانيا : فم التقرارض : }
$$

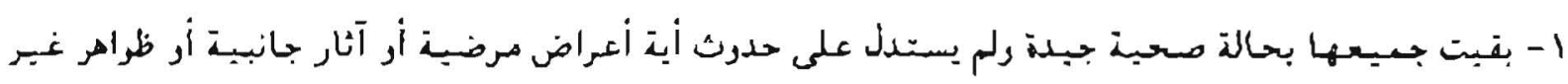

$$
\text { طبيعية. }
$$

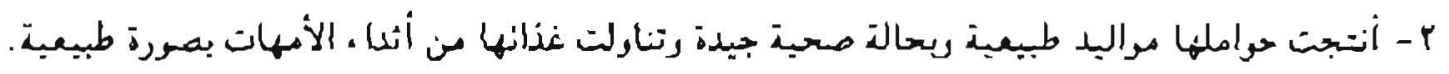
r- بإجرا ، الصفة التشريحية للحيوانات من غير الأمهات رمواليدها - لم يستدل على وجود أية ظواهر باتولرجية.

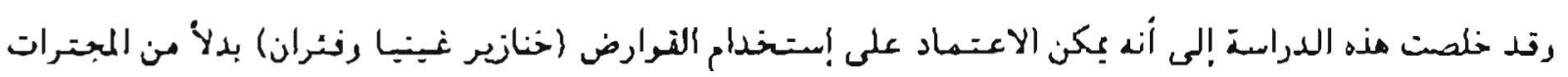
الهغبرة (أغنام وماعز) لتنفيذ إختبار السلامة (salety) كأحد أركان إختبارات السبطرة النوعية للقاح طاعون الجتيرات

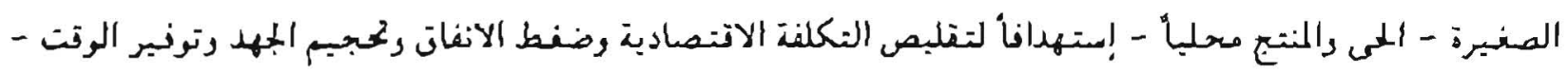

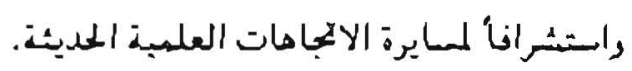

